Agro-Science Journal of Tropical Agriculture, Food, Environment and Extension Volume 16 Number 2 (May 2017) pp. $17-22$

ISSN 1119-7455

\title{
FARMERS' PERCEPTION OF THE ACTIVITIES OF LOWER NIGER BASIN AUTHORITY IN ILORIN EAST LOCAL GOVERNMENT AREA OF KWARA STATE, NIGERIA
}

\author{
Alalade, O.A. ${ }^{1,2}$ Awoyemi, A.O. ${ }^{1}$ Matanmi, B.M ${ }^{1}$. Olaoye, I.J. ${ }^{3}$ and Olaitan, T.R. ${ }^{4}$ \\ ${ }^{1}$ Department of Agricultural Extension and Rural Development, University of Ilorin \\ ${ }^{2}$ Extension Management Division, Department of Rural Development and Gender Issues, \\ Agricultural and Rural Management Training Institute (ARMTI), Ilorin, Nigeria. \\ ${ }^{3}$ Department of Agricultural Economics and Farm Management, University of Ilorin, Nigeria. \\ ${ }^{4}$ Nigeria Stored Product Research Institute (NSPRI) Ilorin, Nigeria \\ ${ }^{2}$ Extension Management Division, Department of Rural Development and Gender Issues, Agricultural \\ and Rural Management Training Institute (ARMTI), Ilorin, Nigeria. \\ e-mail address segunalalade@gmail.com
}

\begin{abstract}
Owing to the huge amount of naira invested into the irrigation sub-sector by the Nigerian government, the study assessed the perception of farmers on the activities of Lower Nigeria River Basin Development Authority (LNRBDA) in Ilorin East local government area of Kwara State, Nigeria. Primary data were used for the study and the data were collected by means of a well-structured questionnaire coupled with interview schedule. A two stage sampling technique was used to select one hundred and six (106) respondents from the list of registered farmers who had participated in the scheme. Descriptive statistics and Pearson Product Moment Correlation were used in analyzing the data. Findings of the study indicated that $98.1 \%$ of the famers had a positive perception on the effectiveness of the scheme. Also, $92.5 \%$ of the respondents reported flexibility in the payment schedule in participating in the LNRBDA irrigation scheme while $81.1 \%$ of the respondents paid for irrigation services install mentally. It was also found that $99.1 \%$ of the respondents experienced increased production output as a result of the use of irrigation facilities. There is a significant relationship between age, farm size and the perception of farmers on some of the activities in the scheme (pvalue < critical p-value of 0.05). The study concludes that farmers' participation and perception in LNRBDA irrigation scheme in the study area is highly encouraging and there is association between age, farm size and the perception of farmers on effectiveness some of the activities of LNRBDA in the study area. It is therefore recommended that government should continue to enhance and strengthens the performance of LNRBDA in the study area.
\end{abstract}

Keywords: Perception, Lower Niger Basin Authority, farmers, Irrigation, Scheme, Production

\section{INTRODUCTION}

Adaption and coping strategies with effects of climate change remain a pertinent issue of discussion among research scholars, policy makers and international communities. Presently, Climate change is perceived the most significant environmental threat facing man and development (Baker, et al., 2015; Agbola, 2011; Cohen et al., 2008). Climate change is the significant deviation from the mean annual temperature of an area and it is reflected in the rapid increase in global temperature. Such change in climate and by implication influences an increase in moisture deficit particularly in semi-arid and even the more humid areas. The associating effects of climate change include global warming, frequent occurrence of drought and flood and other environmental and health disasters. However, drought as one of the effects of climate change has become more frequent (Zoellick, 2009) impacting agriculture, biodiversity, man's health and other sectors in Africa (UNFCCC 2007, IPCC, 2007). Consequently, the change implies that existing agriculture regions will increase reliance on irrigation. With the global climatic change and the rapid encroachment of the Sahara into hither to wet areas of Nigeria middle belt region, the need for irrigation becomes more pressing considering the desire of Nigeria government to assure food security and improve farmers and rural welfare

Please cite as: Alalade, O.A., Awoyemi, A.O., Matanmi, B.M., Olaoye, I.J. and Olaitan, T.R. (2017). Farmers' perception of the activities of Lower Niger Basin Authority in Ilorin East Local Government Area of Kwara State, Nigeria. Agro-Science, 16 (2), 17-22. DOI: https://dx.doi.org/10.4314/as.v16i2.3 
Farmers, Perception of the Activities of Lower Niger Basin Authority

(Federal Ministry of Water Resources, 2006). The Nigeria government interest with the objective of promoting agriculture in water deficient areas through investment in irrigation systems cannot be over emphasized. Over the years, huge resources have been put into the development of irrigation systems and water resource to increase farmers' productivity. History recorded that Nigeria government has spent billions of Naira to construct dams and pumping stations most especially in water deficient areas (Federal Ministry of Water Resources, 2006). Also, in the plight to increase productivity, boost food production and poverty reduction, Nigeria government established many irrigation projects and programs. Notably among them were the Rural Basin Development Authorities (RBDAs), dams and the on-going small-scale Fadama (in-land valley lands which are low-lying and seasonally flooded) development programs by the World Bank assisted project. However, inadequate infrastructures, ineffective marketing system, low human capacity and wrong targeting of government agricultural policies and programs still ravage agricultural system in Nigeria. Hence, the eventuality of wide spread of poverty and food security continue to exist (Liverpool-Tasie,2012; Olokesusi, 1991). Drought and other associating effects of climate change have also been proven to exacerbate these problems. Agricultural production in Nigeria is mainly rain-fed and climate dependent. Majority of farmers depend largely on broad ecological zones resulting from disparity in annual rainfall and the response to climate constraint (Adekunle et al., 2015). Thus, as proposed by the federal government, the focus of LNRBDA which was established in 1976, as a parastatal under the supervision of the federal ministry of agriculture and water resources was on the utilization of the irrigation facilities (PCU, 2002). The utilization of the irrigation facilities and participation of farmers with the parastatal have been low due to wrong perception or inadequate information of their activities. The effect of the large sums of money that have been invested into the irrigation subsector of Nigerian agriculture through the activities of the LNRBDA needs justification. However, the outcomes of these spending have been that of dismal failures, the standard of living of farmers has not improved nor is there any significant increase in crop production (Ekanade, 1994). Thus, given the efforts by the Federal government of Nigeria to realign and restructure the activities of River Basin Authority, this study focused on the perception of farmers on the activities and benefits of the Lower Niger River Basin and Rural
Development Authority in Kwara state. The Lower Niger River Basin and Rural Development Authority is shouldered with the responsibilities and mission of ensuring a sustainable development in the area of irrigated agriculture, rural and urban water supply, flood and erosion control, construction of dams fence and weirs (Adekunle et al.,2015; LNRBDA, 2002). According to Olorunda (2002), the Authority was established to ease the socio-economic stress of farmers but poor funding, mismanagement of funds and corruption have hindered the achievement of the Authority. The determinant of low productivity among farmers are numerous and complex and are to a large extent associated with poor performance of many of the public irrigated scheme which cause low inequitable and unreliable water supplies in those areas (Ekanade, 1994). It is important to know the perception of the farmers on the activities and performance of the Authority in recent time.

However, the need to assess the farmers' perception of the activities and performance of LNRBDA irrigation scheme in Kwara State becomes necessary. There have been limited studies on farmers' perception of the irrigation scheme in the study area. The studies of Olokesusi (1991) and Sangari (1998) on irrigation in the semiarid of Nigeria addressed the technology and methods of assessing irrigation environment vis-àvis the socio-economic implications while recently, Adekunle et al. (2015) considered the factor affecting farmers participation in the irrigation scheme of the LNRBDA. Hence, the main objective of this study was to assess the perception of farmers on the activities of Lower Niger Basin Authority in Ilorin East Local Government Area of Nwara State, Nigeria. Therefore, the specific objectives were to:

i Describe the socio-economic characteristics of the farmers;

ii Examine the perceived benefits of the activities of the LNRBDA on farmers productivity, and

iii Assess the perceptions of farmers about the effectiveness of various activities of Lower Niger River Basin Authority.

\section{Statement of Hypothesis}

$\mathrm{H}_{01}$ :There is no relationship between selected socio-economic characteristics and perception of farmers on the effectiveness of activities in the irrigation scheme.

\section{MATERIALS AND METHODS Study Area}

The study was conducted in Ilorin East Local Government Area of Kwara State, Nigeria. Ilorin is 
Alalade, O.A. Awoyemi, A.O. Matanmi, B.M. Olaoye, I.J. and Olaitan, T.R

the state capital of Kwara state. The state lies between latitude $8^{0}$ and $10^{0} 04^{\mathrm{I}}$ north of the Equator and longitude $2^{0} .45^{\mathrm{I}}$ and $6^{0} .12^{\mathrm{I}}$ East of Greenwich Meridian (Longman, 2000). Kwara State is bounded in the North by Niger State and by River Niger; to the East is Kogi State, while it shares boundary with Oyo, Ondo and Osun States in the south. There are many flowing streams in Kwara State and the state has about 36,820 hectares of farmland (Alalade et al. 2016). All the rivers empty their water into River Niger. The Niger River and its numerous tributaries provide abundant water resources for irrigation activities in the State, especially during the dry season.

\section{Sampling Techniques and Sample Size}

A two stage sampling technique was used for the study. The first stage involves a purposive selection of Ilorin East LGA as the study area. This is because the LGA has the most active irrigation scheme in the State. The second stage involves the use of a systemic random sampling to select $50 \%$ of farmers from the list of the farmers who have participated in the scheme at one time or the other from the association. Thus, a total of one hundred and six (106) respondents were selected which was the sample size used for this study. Data were collected through the use of a well-structured questionnaire coupled with interview schedule. The data collected were analyzed using descriptive statistics and inferential statistics. The descriptive statistics includes; frequency, percentage, and mean scores while the hypotheses was tested using Pearson Products Momentum Correlations (PPMC).

\section{Pearson Product Moment Correlation (PPMC)}

The relationship between socio-economic characteristics of the respondents and the framers' perception of the activities of LNRBDA was measure using the PPMC and this was operationalized using the correlation coefficient (r) formula.

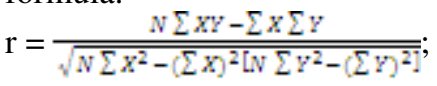

Where

$r=$ correlation coefficient,

Y=Farmers perception of the activities of the LNRBDA irrigation scheme (mean score).

$\mathrm{X}=$ socio-economic characteristics

\section{RESULTS AND DISCUSSION Socio-economic Characteristics of the Respondents}

Findings in Table 1 reveal that all (100\%) the respondents were males while the mean age of the respondents was 41.0 years. This showed that middle-aged generations were more active in rural farming than older generations, who are gradually phasing out of farming activities. Also, farmers are in their economically active years indicating their ability to leverage on this attribute for a high degree of prospects and increased production. This finding is similar to that of Audu and Abu (2005) who reported that people from this age constitute the major work force that can be productive. It is also an inexcusable fact that farming requires a high sense of maturity, vigour and energy which might be difficult for the aged to do. Furthermore, $70.8 \%$ of the respondents were married. This is in line with the finding of Ojo and Mohammed (2008) who in their studies revealed that more than $96 \%$ of their respondents were married. Bolarinwa and Olayinka (2011) also reported similar trend in their study.

Table 1: Socio-economic characteristics of respondents

\begin{tabular}{|c|c|c|c|}
\hline Socio-economic Characteristics & Frequency & Percentage & Mean \\
\hline \multicolumn{4}{|l|}{ Gender } \\
\hline Male & 106 & 100.0 & \\
\hline Female & 0 & 0.00 & \\
\hline \multicolumn{4}{|l|}{ Age } \\
\hline $20-30$ & 19 & 17.9 & 41.0 \\
\hline $31-40$ & 48 & 45.3 & \\
\hline $41-50$ & 29 & 27.4 & \\
\hline $51-60$ & 10 & 9.4 & \\
\hline \multicolumn{4}{|l|}{ Marital Status } \\
\hline Single & 31 & 29.2 & \\
\hline Married & 75 & 70.8 & \\
\hline \multicolumn{4}{|l|}{ Household Size } \\
\hline $2-4$ & 23 & 21.7 & 7.7 \\
\hline $5-7$ & 47 & 44.3 & \\
\hline $8-10$ & 24 & 22.6 & \\
\hline$\geq 11$ & 12 & 11.4 & \\
\hline \multicolumn{4}{|l|}{ Level of Education } \\
\hline Non-formal Education & 26 & 24.5 & \\
\hline Quranic Education & 28 & 26.4 & \\
\hline Primary Education & 23 & 21.7 & \\
\hline Secondary Education & 18 & 17.0 & \\
\hline Tertiary Education & 11 & 10.4 & \\
\hline \multicolumn{4}{|l|}{ Faming experience } \\
\hline $1-5$ & 5 & 4.7 & 13.0 \\
\hline $6-10$ & 39 & 36.8 & \\
\hline $11-15$ & 29 & 27.4 & \\
\hline $16-20$ & 10 & 9.4 & \\
\hline$\geq 21$ & 23 & 21.7 & \\
\hline \multicolumn{4}{|l|}{$\begin{array}{l}\text { Prior Knowledge of } \\
\text { LNRBDA Irrigation }\end{array}$} \\
\hline Yes & 98 & 92.5 & \\
\hline No & 8 & 7.5 & \\
\hline
\end{tabular}

Table 2: Farmers Perceived Benefit of LNRBDA activities in the study area

\begin{tabular}{lll}
\hline Increase Productivity & Frequency & Percentage \\
\hline & & \\
Yes & 104 & 98.1 \\
No & 3 & 1.9 \\
Total & 106 & 100 \\
\hline Source: Field Survey, 2012 &
\end{tabular}


Farmers, Perception of the Activities of Lower Niger Basin Authority

Table 3: Distribution of respondents based on perception

\begin{tabular}{lllll}
\hline & $\begin{array}{l}\text { Very } \\
\text { Satisfactory }\end{array}$ & Fairly Satisfactory & $\begin{array}{l}\text { Not } \\
\text { Satisfactory }\end{array}$ & Mean \\
\hline Quality of water supplied for irrigation & $101(95.3)$ & $5(4.7)$ & - & 2.95 \\
Quantity of water supplied for irrigation & $7(6.60)$ & $18(16.98)$ & $81(76.42)$ & 1.30 \\
Land Preparation & $85(80.2)$ & $21(19.8)$ & - & 2.80 \\
Size of land allocated to farmers & $95(89.6)$ & $11(10.4)$ & - & 2.90 \\
Land allocation fee & $84(79.2)$ & $21(19.8)$ & $1(0.9)$ & 2.78 \\
Water allocation fee & $14(13.2)$ & $43(40.6)$ & $49(46.2)$ & 1.67 \\
Timeliness of land allocation to farmers & $82(77.4)$ & $22(20.8)$ & $2(1.8)$ & 2.75 \\
Timeliness of water supplied to farmers & $22(20.8)$ & $82(77.4)$ & $2(1.8)$ & 2.18 \\
Technical support & $52(49.1)$ & $50(47.2)$ & $4(3.7)$ & 2.45 \\
Information on marketing opportunity & $14(13.2)$ & $49(46.2)$ & $43(40.6)$ & 1.73 \\
Advisory services & $56(52.8)$ & $45(42.5)$ & $5(4.7)$ & 2.48 \\
\hline
\end{tabular}

Source: Field Survey, (2012)

Table 4: Benefits derived from the scheme

\begin{tabular}{|c|c|c|c|}
\hline tems & & Frequency & Percentage \\
\hline \multirow[t]{2}{*}{ Increase in socio-status } & Yes & 100 & 94.3 \\
\hline & No & 06 & 5.70 \\
\hline Improvement in skill & & 105 & 99.1 \\
\hline \multirow{2}{*}{ \& knowledge } & Yes & 01 & 0.9 \\
\hline & No & & \\
\hline \multirow[t]{2}{*}{ Satisfactory service } & Yes & 105 & 99.1 \\
\hline & No & 01 & 0.9 \\
\hline \multirow{2}{*}{$\begin{array}{l}\text { Flexibility in mode of } \\
\text { payment }\end{array}$} & & 97 & 91.5 \\
\hline & $\begin{array}{l}\text { Yes } \\
\text { No }\end{array}$ & 9 & 8.50 \\
\hline \multirow[t]{2}{*}{ Technical support } & Yes & 88 & 83.1 \\
\hline & No & 18 & 16.9 \\
\hline \multirow{2}{*}{$\begin{array}{l}\text { Information on market } \\
\text { opportunity }\end{array}$} & Yes & 93 & 87.7 \\
\hline & No & 13 & 13.3 \\
\hline
\end{tabular}

This implies that most of the farmers have a strong family responsibility ties that will require more financial commitment on the part of the farmers hence the need to get the best out of farming so as to enhance their income. Only $10.4 \%$ of the respondents had tertiary education. This is also in consonance with the finding of Ndanitsa (2005) and Tsoho (2005) who in their separate study reported that rural farmers are characterized with low level of literacy. Also, $44.3 \%$ of the respondents have between 5 and 7 household sizes while majority $(36.8 \%)$ had 6-10 years farming experience. This indicated that farming household has large household size which might be as a result of high need for man power in all farming activities.

\section{Perception of Farmers on Activities of LNRBDA}

Table 2 reveals that majority $(92.5 \%)$ of the respondents had prior knowledge of irrigation before their involvement in the LNRBDA scheme and $98.2 \%$ of the respondents admitted that the irrigation scheme increase their productivity. While Table 3, majority (95.3\%) of the respondents believed that the quality of water supplied for irrigation was very satisfactory while only few $(6.6 \%)$ of the respondents believed that the quantity of water supplied for irrigation was very satisfactory most especially during the dry season farming. More so, based on other activities benefited by the LNRBDA farmer participants, the result (Table 3 ) revealed that $80.2 \%$ of respondents believed land preparation was very satisfactory and $89.6 \%$ of the respondents supposed that the size of land allocation was very satisfactory. The table also shows that $79.2 \%$ of the respondents believed that land allocation fee was very satisfactory and only few $(13.2 \%)$ of the respondents believed information on marketing opportunities provided by LNRBDA were very satisfactory, while on advisory services given by LNRBDA, $52.8 \%$ of the respondents believed that this was very satisfactory. On water allocation, only few (13.2\%) of the respondents agreed that it was very satisfactory. This result was in consonance with the report of Adekunle et al., (2015) and Oriola, (2006) that insufficient water, unreliable supply and distribution irrigation water were factors that discouraged farmers participating in LNRBDA irrigation scheme. Therefore, the performance of the LNRBDA irrigation scheme could be adjudged below average given that the main function of the scheme is yet to be fully addressed.

\section{Benefits Derived by the Farmers from the Scheme}

Table 4 revealed the benefits derived by farmers who participated in the scheme. About $94.3 \%$ of the respondents agreed that the scheme has led to a drastic increase in their social status. By implication, there has been a drastic increase in the standard of living of the farmers through the scheme. Omotayo, (2008) noted that the ultimate goal of government's involvement in farming is to bring about an increase in the standard of living of rural farmers. 
Alalade, O.A. Awoyemi, A.O. Matanmi, B.M. Olaoye, I.J. and Olaitan, T.R

Table 5: Relationship between socio-economic characteristics and perception of farmers on activities of the scheme

\begin{tabular}{|c|c|c|c|}
\hline \multirow[t]{2}{*}{ Perceptions } & \multicolumn{3}{|c|}{ Socio-economic characteristics } \\
\hline & Age & Farming experience & Farm size \\
\hline Quantity of water supplied & $0.184 *(0.059)$ & $0.133(0.175)$ & $-0.053(0.557)$ \\
\hline Land preparation & $0.220 * *(0.023)$ & $0.146(0.134)$ & $0.044(0.651)$ \\
\hline Size of land allocation & $0.103(0.293)$ & $-0.018(0.853)$ & $0.209 * *(0.032)$ \\
\hline Land allocation fee & $0.088(0.372)$ & $-0.027(0.785)$ & $-0.045(0.649)$ \\
\hline Water allocation fee & $0.095(0.331)$ & $-0.003(0.972)$ & $0.120(0.219)$ \\
\hline Timeliness of land preparation & $0.015(0.880)$ & $-0.044(0.653)$ & $0.285 * *(0.003)$ \\
\hline Timeliness of water & $0.041(0.673)$ & $0.100(0.104)$ & $0.157(0.108)$ \\
\hline Technical support & $-0.219 * *(0.024)$ & $-0.053(0.593)$ & $-0.025(0.802)$ \\
\hline Information on marketing & $0.013(0.897)$ & $0.046(0.639)$ & $0.082(0.406)$ \\
\hline
\end{tabular}

Source: Field Survey, (2012) figure in parenthesis is P-Value

** significant at $\mathrm{Pv}=5 \%$, *significant at $\mathrm{Pv}=10 \%$

Also, $99.1 \%$ of the respondents stated there has been an improvement in their skill and knowledge as a result of participating in the scheme. On the other hand, $91.5 \%$ of the espondents described the mode of payment for services rendered as flexible while $99.1 \%$ also described the services rendered as satisfactory. On market opportunity, $87.7 \%$ of the respondents agreed they received good and timely information on market opportunities while $83.1 \%$ were satisfied with the quality of technical support rendered. Furthermore, $87.7 \%$ of the respondents agreed to timeliness in land allocation which no doubt has contributed to the success of the scheme.

\section{Test of Hypothesis}

Table 5 shows the relationship between selected socio-economic characteristics and perception of farmers on the effectiveness of activities in the scheme. It was revealed that age have a significant associations with the farmers perception on the effectiveness of the technical support provided and land preparation activities by the scheme (p-value < 0.05 ) while that of the perception on quality of irrigated water supply was significant at $\mathrm{p}$-value of $10 \%$ (i.e p-value $=0.059<$ critical p-value of 0.10 ). Also, there is a significant association between land size and farmers perception on the effectiveness of assistance provided on land preparation $(\mathrm{r}=0.209)$ and size of land allocation for irrigation $(r=0.285)$ by the LNRBDA in the study area (p-value < 0.05 ). The higher the correlation coefficient, the better the degree of co-movement between the selected socioeconomic variables and the farmers perception on the effectiveness of the LNRBDA activities in the study area. Although, an inverse association ( $\mathrm{r}=$ 0.219 , p-value $<0.05)$ was observed the relationship between age technical support provided by the LNRBDA. This indicates that as age increases the lesser is the technical support provided by the scheme and vice versa. However, this might be because as man grows older, his breadth of knowledge and experiences increase and the lesser man might likely depend on technical support he might has acquire the technical knowledge through past experience. This was however in agreement with the report of Olumba and Raji (2014) that as age increases, experience can be tapped to improve the respondents farming prowess.

\section{CONCLUSION AND RECOMMENDATIONS}

The study concluded that farmers' perception of Lower Niger River Basin Development Authority (LNRBDA) irrigation scheme in Ilorin-east LGA of Kwara State is high and very satisfactory. The factors that influenced farmers' participation lie in the flexibility in payment schedule in partaking in the irrigation scheme. As a result of their participation in the scheme, majority of the farmers perceived a significant increase in their productivity which brings about more income. In lieu of these, the following recommendations were made:

i Government should continue to enhance and strengthens the performance of river basin authority in the area

ii Government must ensure meaningful participation of farmers in LNRBDA areas in designing, implementings, monitoring and evaluating the irrigation scheme.

iii Alongside the improvement of irrigation system, efforts must be made by all stakeholders to develop sustainable policies on land and water use, quantity of water supply for irrigation, land and water allocation fees, timeliness of land and water supplied and market and marketing opportunities. These will go a long way in increasing farmers' participation in LNRBDA irrigation scheme in Ilorin-east LGA of Kwara State, which will in turn boost productivity thereby ensuring food security. 
Farmers, Perception of the Activities of Lower Niger Basin Authority

\section{REFERENCES}

Adekunle, O. A., 8 Oladipo, F. O.9 \& Busari I. Z.10. (2015): Factors Affecting Farmers' Participation in Irrigation Schemes of the Lower Niger River Basin and Rural Development Authority, Kwara State, Nigeria. S.Afr. Tydskr. Landbouvoorl./S. Afr. J. Agric. Ext., Vol. 43, No. 2: 42 - 51 DOI: http://dx.doi.org/10.17159/24133221/2015/v43n2a353

Agbola, B. (2011). Climate Change and Poverty in Nigeria, 32(1)54-79.

Alalade, O. A., Matanmi, B. M., Olaoye, I. J. \& Tifase, O. A. (2016) Perception of Poultry Farmers on the Effect of Mobile Telephony on Poultry Production in Kwara State, Nigeria. Journal of Science, Technology, Mathematics and Education (JOSTMED), 12(2):80-88

Audu and Abu (2005). ICTs Application in agricultural extension services delivery. In: SF Adedoyin (Ed): Agricultural Extension in Nigeria. Ilorin: Agricultural Extension Society of Nigeria. pp. 245251

Baker, J., DL, B., Bell, J., \& Chang, S. D. (2015). Climate change adaptation guided by the law. Brisbane.

Bolarinwa, K. and Oyeyinka, R. (2011). Use of cell phones by farmers and its implication on farmers' production capacity in Oyo state, Nigeria. World Academy of Science, Engineering and Technology (Vol. 75).

Cohen, M. J., \& Garrett, J. L. (2010). The food price crisis and urban food (in)security. Environment and Urbanization, 22(2), $467 \quad-482$. doi:10.1177/0956247810380375

Ekanade, O (1994). Preliminary Investigation of Soil Patterns in Large Scale Agricultural Project in Nigeria." In A. O. Sanda and S. B Ayo (Eds.), Impact of irrigation projects in Nigeria's Environment. Anchor print Ltd Ibadan, pp 40-52.

Federal Ministry of Water Resources (2006). Performance and Achievements of the

Federal Ministry of Water Resources 2007 Bulletin. Abuja.

Federal Ministry of Water Resources under the Obasanjo Administration 1999 - 2006.

IPCC. (2007). Climate Change 2007: Impacts, Adaptation and Vulnerability. Summary for Policy Makers. Retrieved from http://www.ipcc.cg/SPM13apr07.pdf

Liverpool-Tasie, L. S. O . 2012. Farmer Groups, Input Access and Intragroup Dynamics: A Case Study of Targeted Subsidies in Nigeria. Discussion Paper 01197. Washington, DC: International Food Policy Research Institute
Middleton N. (1997). The Global Casino: An Introduction to Environmental Issues. PP 99- 113.

Ndanitsa and Tsoho (2005): Customer Acquisition among Small and Informal Businesses in Urban India: Comparing Face to Face and Mediated Channels. Electronic Journal of Information Systems in Developing Countries.32 (3): pp 2-14.

Needham, J. (1986). Science and Civilization in China: Volume 4, Physics and Physical Technology, Part 2, Mechanical Engineering. Taipei: Caves Books Ltd. Pages 344-346.

Olokesusi, A.O. (1991). Framework for Environmental Impact and Assessment in Nigeria: Case Study of Large Scale Irrigation Projects in the SudanoSahelian Zone Unpublished PhD Thesis Department of Geography University of Ibadan.

Olorunda, (2002): "Climate and the Planning of Agriculture Land Use in Nigeria. The N R B D A area as A Case Study". Journal of Agriculture Meteorology. 43: (4) 285-294

Olumba, C.C. and M. A.Y. Rahji (2014), An Analysis of the Determinants of the Adoption of Improved Plantain Technologies in Anambra State, Nigeria. Journal of Agriculture and Sustainability Volume 5, Number 2, 232-245

Omotayo, A.M. (2008): Poultry Farmers willingness to Participate in NACIC Scheme in Ogun State. In: Oduguwa et al., (eds) Proceeding of the Silver Anniversary Conference of NSAP Gateway Hotel Abeokuta, pp.542

Project Coordinator Unit (PCU) (2002): Crop Area Yield Survey. Federal Ministry of Agricultural and Rural. Federal Ministry of Agricultural and Rural Development, Abuja

Sangari, D.U. (1991). A Comparative Analysis of Traditional and Modern Systems of Irrigated Agriculture in the Donga River Basin Gongola State. Unpublished Ph.D. Thesis. Department of Geography, University of Ibadan.

UNFCCC. (2007). Climatic Change Impact, Vulnerabilities and Adaptation in Developing Countries. Bonn, Germany.: UNFCCC Secretariat,. Retrieved from www.unfccc.int

Zoellick, R. B. . (2009). Climate Smart Future. The Nation Newspapers. Vintage Press Limited, p. 18pp. Lagos, Nigeria. 